\title{
Tuberculosis in children treated with second-line drugs under programmatic conditions in Lima, Peru
}

\author{
J. Villarreal, ${ }^{*}$ V. Alarcón, ${ }^{\dagger}$ E. Alarcón-Arrascue, ${ }^{\ddagger}$ D. A. J. Moore, ${ }^{\S}$ E. Heldal, ${ }^{\natural 1}$ A. Mendoza-Ticona\# \\ *Hospital de Huaycán, Ministerio de Salud, Lima, 'Estrategia Sanitaria Nacional de Prevención y Control de la \\ Tuberculosis, Ministerio de Salud, Lima, Peru; ${ }^{\ddagger}$ Organización Panamerica de Salud, Washington, DC, USA; ${ }^{\S}$ London \\ School of Hygiene \& Tropical Medicine, London, UK; "International Union Against Tuberculosis and Lung Disease, \\ Oslo, Norway; "Hospital de Emergencias Villa El Salvador, Ministerio de Salud, Lima, Peru
}

S U M M A R Y

OBJECTIVE: To characterise childhood tuberculosis (TB) treated with second-line drugs (SLDs) in Lima, Peru.

DESIGN: Results for the age groups $<5$ and 5-14 years were compared and treatment outcomes were assessed in cases reported between 2011 and 2015 from six districts of Lima.

RESULTS: Of 96 reported cases, 82 were evaluated. Among these, $59 \%$ were boys; the median age was 8 years and $32 \%$ were aged $<5$ years. Contact with a TB case was reported in $82 \%$ of cases; $90 \%$ were treatmentnaïve, $98 \%$ had pulmonary localisation and $50 \%$ underwent the tuberculin skin test (purified protein derivative), with induration $\geqslant 10 \mathrm{~mm}$ in $88 \%$. A positive smear was found in $40 \%$, all in the 5-14 years age group, and $46 \%$ were culture-positive. Only $26 \%$ had confirmed multidrug-resistant TB, $90 \%$ of whom were in the 5-14 years age group. SLDs for confirmed or probable drug-resistant TB (DR-TB) were administered to all cases, with a high proportion of success (over $83 \%$ ), no failures or deaths and a high proportion of loss to follow-up.

CONCLUSION: The main indication for SLDs in childhood TB was the empirical treatment of DR-TB due to contact with one or more identified DR-TB patients. Bacteriological confirmation was limited; however, treatment success was adequate.

KEY WORDS: children TB; SLDs; treatment outcome; MDR-TB; multidrug-resistant tuberculosis
ALTHOUGH THE ACTUAL RATE of childhood tuberculosis (TB) is not known, in 2016 the World Health Organization (WHO) estimated that there were 1 million new cases of childhood TB, accounting for about $6.9 \%$ of all estimated new cases worldwide. ${ }^{1}$ Estimation of drug-resistant TB (DR-TB) in children is limited because bacteriological confirmation of drug resistance in childhood TB cases is difficult; it has nevertheless been estimated that $15 \%$ of multidrug-resistant TB (MDR-TB) cases occur in children aged $<15$ years. ${ }^{2}$ Small children develop paucibacillary or extra-pulmonary $\mathrm{TB}$, they cannot expectorate and this limits TB bacteriological confirmation; physicians are thus forced to base their diagnosis on a number of criteria, the most important of which are the clinical picture, history of contact (epidemiological), tuberculin reaction and imaging or histopathology studies. ${ }^{3}$ Due to the limitations in confirming DR-TB in children, treatment is often based on the resistance profile of the index case, who is usually an adult in the family. ${ }^{4}$

In Peru, of the 30000 TB cases reported in 2014, $7.7 \%$ were childhood TB, $54 \%$ of whom had negative smear or no bacilloscopy. It was estimated that $3-5 \%$ of childhood forms were MDR-TB and were treated with second-line drugs (SLDs). ${ }^{5,6}$ Other treatment indications for SLDs in children are isoniazid (INH) resistant TB without MDR-TB, and severe adverse reactions (ADRs) to first-line drugs. Programmatically, treatment response in children who receive SLDs is not monitored, and the dimension of bacteriological confirmation or the clinical-epidemiological profile of these childhood TB cases is not known.

The objective of the present study was to describe the clinical-epidemiological characteristics and treatment outcomes of childhood TB patients treated with SLDs in six districts, diagnosed between 2011 and 2015 in Eastern Lima, Peru, where the DR-TB rate is the highest in the country.

\section{MATERIALS}

This was an operational research study using a retrospective cohort design.

Correspondence to: José Enrique Villarreal Palomino, Hospital de Huaycán, Ministerio de Salud, Avenida J C Mariátegui, S/ N Zona 'B' Huaycán, Ate, Lima, Peru. e-mail: jvillarrealp69@yahoo.com

Article submitted 13 December 2017. Final version accepted 25 May 2018.

[A version in Spanish of this article is available from the Editorial Office in Paris and from the Union website www.theunion.org] 


\section{Study site}

The study was conducted in the Lima Este Metropolitan Network of the Ministerio de Salud (MINSA). It comprises the six districts (population approximately 1554000 ) of El Agustino, Santa Anita, Ate, Lurigancho-Chosica, Cieneguilla y Chaclacayo. Since 2008, MINSA has gradually implemented universal access to MDR-TB diagnosis using rapid tests endorsed by the World Health Organization (WHO), such as the microscopic-observation drug susceptibility (MODS) assay, GenoType ${ }^{\circledR}$ MTBDRplus (Hain Lifescience, Nehren, Germany) and the nitrate reductase assay (Griess test). ${ }^{7,8}$ Contact investigation is mandatory for all household members and close contacts of the index case outside the home, independent of age or human immunodeficiency virus (HIV) status. The diagnosis of paediatric cases is based on clinical, epidemiological (TB contact identification), microbiological (smear and culture, not molecular testing), immunological (tuberculin skin test), radiological (X-ray and computed tomography) and histopathological criteria. Cases that are difficult to diagnose are referred to paediatric pulmonologists in regional hospitals. Diagnosis and treatment of susceptible and resistant TB are free of charge for the patient and administered on an outpatient basis at primary health care sites. The duration and composition of the treatment regimens are based on the $2011 \mathrm{WHO}$ guidelines for DR-TB treatment. ${ }^{9}$

\section{Study population}

Patients aged $<15$ years notified with a TB diagnosis and started on treatment with SLDs between 2011 and 2015 were identified from the Electronic Medical Records (EMRs) of Peru's MINSA National Programme for Tuberculosis Prevention and Control. Patients were excluded if their clinical records and treatment cards could not be retrieved from the health care sites where they were treated or if they did not belong to the Lima Este Metropolitan Network.

\section{Data collection}

During the first quarter of 2016, 36 health care sites where children received treatment were visited by one of the authors. Clinical records, treatment cards and TB case registers were reviewed; data were collected in a previously validated questionnaire containing the variables age, date of birth, district of origin, date of TB diagnosis, date of DR-TB diagnosis, treatment initiation, history of contact at home and its characteristics, DR-TB contacts and patient resistance profile, complementary tests, indications for treatment with SLDs, drugs administered, treatment outcomes and reason for discontinuing the regimen. Data regarding ADRs were not collected due to the high probability of underreporting in medical records.

\section{Statistical analysis}

Epidemiological and clinical characteristics were compared between patients aged $<5$ and those aged 5-14 years. A $\chi^{2}$ test or Fisher's exact test was used to assess the difference between categorical variables. $P$ $<0.05$ was considered statistically significant. The database was created using Epi Info ${ }^{\text {TM }} 7.0$ (Centers for Disease Control and Prevention, Atlanta, GA, USA) and was analysed using Stata v14 (StataCorp, College Station, TX, USA).

\section{Ethical considerations}

The study protocol was approved by the Ethics Committee at the Hospital Nacional Hipólito Unanue, Lima Este, Peru, and the Ethics Advisory Group of the International Union Against Tuberculosis and Lung Disease (The Union), Paris, France.

\section{RESULTS}

Using the EMR, 96 children with the screening criteria were identified, 14 of whom were excluded from the analysis: five were from a different district and in nine the clinical records could not be retrieved. The evaluated population comprised 48 males $(59 \%)$ and 34 females $(41 \%)$. The median age was 8 years, with an interquartile range (IQR) of 4-12 years for the overall group; the median age was 8.5 years in boys (IQR 3-12) and 8 years in girls (IQR 4-12). Tables 1 and 2 show the main clinical and epidemiological characteristics of the population, and compare the $26(32 \%)$ children aged $<5$ years with the 56 (68\%) children aged 5-14 years.

Of the study population, $80 \%$ came from three districts: El Agustino, Santa Anita and Ate. In 67 cases of childhood TB, at least one contact with TB was identified; of these, 63 cases $(94 \%)$ had contacts at home, 30 of whom $(48 \%)$ had two or more contacts with TB. The most common relations were mother and uncle. Of the 99 TB cases identified among contacts, $51 \%$ had MDR-TB and $15 \%$ extensively drug-resistant TB (XDR-TB), with no significant differences between the two age groups (Table 1 ). Most children aged $<5$ years were detected through contact investigation $(73 \%)$, while children aged 5-14 years were identified through out-patient visits $(75 \%)$ : this difference was statistically significant $(P<0.001)$.

In the 5-14 years age group, 52\% started treatment with first-line drugs and then switched to SLDs after drug susceptibility testing (DST) results became available, while a significantly higher proportion of children aged $<5$ years $(77 \%)$ were treated with SLDs from the start $(P<0.004)$. Treatment was started for confirmed MDR-TB disease in $26 \%$ of 
Table 1 Epidemiological characteristics of children with TB treated with second-line drugs in Lima Este, Peru, 2011-2015

\begin{tabular}{|c|c|c|c|c|}
\hline Characteristics & $\begin{array}{c}0-4 \text { years } \\
(n=26) \\
n(\%)\end{array}$ & $\begin{array}{c}5-14 \text { years } \\
(n=56) \\
n(\%)\end{array}$ & $\begin{array}{c}\text { Total } \\
(n=82) \\
n(\%)\end{array}$ & $P$ value \\
\hline Male sex & $16(62)$ & $32(57)$ & $48(59)$ & 0.7 \\
\hline History of TB household contact & $25(96)$ & $38(68)$ & $63(77)$ & 0.018 \\
\hline History of TB contact outside the home & 0 & $4(7)$ & $4(5)$ & \\
\hline Two or more TB contacts in the home ${ }^{\dagger}$ & $10(40)$ & $20(53)$ & $30(48)$ & 0.34 \\
\hline \multicolumn{4}{|l|}{ Relationship with the most likely index case ${ }^{\ddagger}$} & 0.97 \\
\hline Mother & $8(32)$ & $15(39)$ & $23(37)$ & \\
\hline Uncle & $9(36)$ & $14(37)$ & $23(37)$ & \\
\hline Father & $4(16)$ & $6(16)$ & $10(16)$ & \\
\hline Sibling & $3(12)$ & $4(11)$ & $7(11)$ & \\
\hline Other & $1(4)$ & $3(8)$ & $4(6)$ & \\
\hline \multicolumn{4}{|l|}{ Profile of DR-TB contacts identified $(n=99)^{\S}$} & 0.48 \\
\hline MDR-TB & $13(52)$ & $21(50)$ & $48(51)$ & \\
\hline XDR-TB & $2(8)$ & $8(19)$ & $12(15)$ & \\
\hline Other DR-TB, non-MDR-TB & $8(32)$ & $12(29)$ & $30(30)$ & \\
\hline Not specified & $2(8)$ & $1(2)$ & $9(4)$ & \\
\hline BCG scar present & $20(77)$ & $36(64)$ & $56(68)$ & 0.38 \\
\hline \multicolumn{4}{|l|}{ Previous treatment history } & 0.22 \\
\hline Never treated & $25(96)$ & $49(88)$ & $74(90)$ & \\
\hline Previously treated & $1(4)$ & $7(12)$ & $8(10)$ & \\
\hline \multicolumn{4}{|l|}{ Case detection process } & $<0.001$ \\
\hline Out-patient visit & $7(27)$ & $42(75)$ & $49(60)$ & \\
\hline Contact study & $19(73)$ & $14(25)$ & $33(40)$ & \\
\hline \multicolumn{5}{|l|}{$\S$ Percentage of the 99 TB index cases identified. } \\
\hline
\end{tabular}

patients, in $57 \%$ for probable DR-TB, in $10 \%$ for resistance to $\mathrm{INH}$, and in $7 \%$ due to a regimen change caused by ADRs or other reasons. Among children aged $<5$ years, $88 \%$ were initiated on SLDs due to probable DR-TB and $8 \%$ due to confirmed MDR-TB; this was significantly different from the 5-14 years age group (respectively $43 \%$ and $34 \%$ ). In $55 \%$ of cases, no DST was performed; the treatment regimen was based solely on the index case's regimen, except for cases who were admitted with an ADR. Among the 37 patients with DST results, 34 (92\%) belonged to the $5-14$ years age group; $60 \%$ had MDR-TB and $23 \%$ were INH-resistant; $34 \%$ were detected using rapid assays (MTBDRplus, MODS and Griess) and the rest using the proportion method. The overall test results showed $78 \%$ with resistance to INH, $57 \%$ to rifampicin, $60 \%$ to streptomycin, $60 \%$ to pyrazinamide and $32 \%$ to ethambutol.

More patients in the 5-14 years age group had clinical manifestations $(84 \%)$ than in the under 5 group $(50 \%)$. The most common symptoms were cough, weight loss and appetite loss, and differed significantly between the two groups (Figure 1). The most commonly used criteria for diagnosis in children aged $<5$ years were radiological, epidemiological and immunological (Figure 2).

At the time of evaluation, 22 patients were still on treatment. Among the 60 patients with treatment results, $14(23 \%)$ had confirmed MDR-TB, 34 (57\%) probable DR-TB (contact with a DR-TB index case), $8(13 \%)$ were INH-resistant but not MDR-TB and 4 $(7 \%)$ were treated for ADRs (Table 3). Treatment success was high, at between $83 \%$ and $100 \%$; $11-$ $17 \%$ of patients were lost to follow-up, and there were no failures or deaths. The treatment regimen was not changed in any of the cases due to ADRs. Figure 3 shows the drugs used according to the type of diagnosis (confirmed or probable DR-TB). Only drugs from WHO Groups 1-4 were used, according to the 2011 WHO guidelines for DR-TB treatment. ${ }^{9}$

\section{DISCUSSION}

This report presents the epidemiological and clinical characteristics of childhood TB treated programmatically with SLDs in a high MDR-TB prevalence area in Lima. Of note are the limitations in TB bacteriological diagnosis and TB drug resistance detection in this population; however, we report a high treatment success rate, which is consistent with other studies from Peru and other developing countries. ${ }^{4,10}$

Most children aged $<5$ years were identified by contact investigation $(96 \%)$, consistent with international evidence, ${ }^{11,12}$ while $75 \%$ of cases in the $5-14$ years age group were detected on consultation for active disease. This finding suggests limitations in the study of TB contacts in this age group, given that contact investigation of all household contacts is 
Table 2 Clinical characteristics of children with TB treated with second-line drugs in Lima Este, Peru, 2011-2015

\begin{tabular}{|c|c|c|c|c|}
\hline Characteristics & $\begin{array}{c}0-4 \text { years } \\
(n=26) \\
n(\%)\end{array}$ & $\begin{array}{c}5-14 \text { years } \\
(n=56) \\
n(\%)\end{array}$ & $\begin{array}{c}\text { Total } \\
(n=82) \\
n(\%)\end{array}$ & $P$ value* \\
\hline $\begin{array}{l}\text { Nutritional status } \\
\text { Well nourished } \\
\text { Acute malnutrition } \\
\text { Chronic malnutrition }\end{array}$ & $\begin{array}{c}23(88) \\
3(12) \\
0\end{array}$ & $\begin{array}{l}41(73) \\
13(23) \\
2(4)\end{array}$ & $\begin{array}{l}64(78) \\
16(20) \\
2(2)\end{array}$ & 0.25 \\
\hline $\begin{array}{l}\text { PPDs performed } \\
\text { PPD } \geqslant 10 \mathrm{~mm}\end{array}$ & $\begin{array}{l}22(85) \\
20(77)\end{array}$ & $\begin{array}{l}19(34) \\
16(29)\end{array}$ & $\begin{array}{l}41(50) \\
36(44)\end{array}$ & $\begin{array}{c}<0.001 \\
0.51\end{array}$ \\
\hline $\begin{array}{l}\text { Sputum smear test } \\
\text { Negative } \\
\text { Paucibacillary } \\
\text { AFB }+ \\
\text { AFB }++ \\
\text { AFB }+++\end{array}$ & $\begin{array}{l}2(8) \\
2(100) \\
0 \\
0 \\
0 \\
0\end{array}$ & $\begin{aligned} 48 & (86) \\
15 & (31) \\
2 & (4) \\
13 & (27) \\
3 & (6) \\
15 & (31)\end{aligned}$ & $\begin{aligned} 50 & (61) \\
17 & (34) \\
2 & (4) \\
13 & (26) \\
3 & (6) \\
15 & (30)\end{aligned}$ & $<0.001$ \\
\hline $\begin{array}{l}\text { Gastric aspirate culture } \\
\text { Negative } \\
\text { Positive }\end{array}$ & $\begin{array}{r}21(81) \\
18(86) \\
3(14)\end{array}$ & $\begin{array}{l}8(14) \\
8(100) \\
0(0)\end{array}$ & $\begin{array}{r}29(35) \\
26(90) \\
3(10)\end{array}$ & $\begin{array}{r}<0.001 \\
0.73^{*}\end{array}$ \\
\hline $\begin{array}{l}\text { Sputum culture } \\
\text { Positive }\end{array}$ & $\begin{array}{c}23(88) \\
1(4)\end{array}$ & $\begin{array}{l}56(100) \\
37(66)\end{array}$ & $\begin{array}{l}79(96) \\
38(46)\end{array}$ & $\begin{array}{c}0.06 \\
<0.001\end{array}$ \\
\hline $\begin{array}{l}\text { TB localisation } \\
\text { Pulmonary } \\
\text { Extra-pulmonary }\end{array}$ & $\begin{array}{c}25(96) \\
1(4)\end{array}$ & $\begin{array}{c}55(98) \\
1(2)\end{array}$ & $\begin{array}{l}79(96) \\
2(2)\end{array}$ & $0.54 *$ \\
\hline On SLDs since initiation & $20(77)$ & $27(48)$ & $47(57)$ & $<0.004$ \\
\hline $\begin{array}{l}\text { Reason for SLD initiation } \\
\text { Probable DR-TB disease } \\
\text { Confirmed MDR-TB disease } \\
\text { Confirmed INH-resistant, non-MDR disease } \\
\text { Adverse drug reactions } \\
\text { Other reasons }\end{array}$ & $\begin{aligned} & 23(88) \\
& 2(8) \\
& 1(4) \\
& 0 \\
& 0\end{aligned}$ & $\begin{array}{l}24(43) \\
19(34) \\
7(13) \\
4(7) \\
2(4)\end{array}$ & $\begin{array}{l}47(57) \\
21(26) \\
8(10) \\
4(5) \\
2(2)\end{array}$ & $\begin{array}{c}<0.001 \\
0.011 \\
0.209^{*} \\
0.210^{*} \\
0.462^{*}\end{array}$ \\
\hline $\begin{array}{l}\text { Hospitalisation during treatment } \\
\text { Patients with DST results }\end{array}$ & $\begin{array}{l}2(8) \\
3(12)\end{array}$ & $\begin{array}{l}10(18) \\
34(61)\end{array}$ & $\begin{array}{l}12(15) \\
37(45)\end{array}$ & $\begin{aligned} & 0.193^{*} \\
&<0.001\end{aligned}$ \\
\hline $\begin{array}{l}\text { Classification based on child susceptibility pattern } \\
\text { MDR-TB } \\
\text { INH-resistant TB, without MDR-TB } \\
\text { Pansusceptible } \\
\text { Polyresistant TB } \\
\text { Other resistance }\end{array}$ & $\begin{array}{l}2(67) \\
1(33) \\
0 \\
0 \\
0\end{array}$ & $\begin{aligned} & 19(59) \\
& 7(22) \\
& 5(16) \\
& 2(6) \\
& 1(3)\end{aligned}$ & $\begin{aligned} & 21(60) \\
& 8(23) \\
& 5(14) \\
& 2(5) \\
& 1(3)\end{aligned}$ & 0.86 \\
\hline
\end{tabular}

* Fisher's exact test; the remaining $P$ values were calculated using the $\chi^{2}$ test.

$\mathrm{TB}=$ tuberculosis; $\mathrm{PPD}=$ purified protein derivative; $\mathrm{AFB}=$ acid-fast bacilli; SLD = second-line drugs; DR-TB = drugresistant TB; MDR-TB = multidrug-resistant TB; DST = drug susceptibility testing; INH = isoniazid.

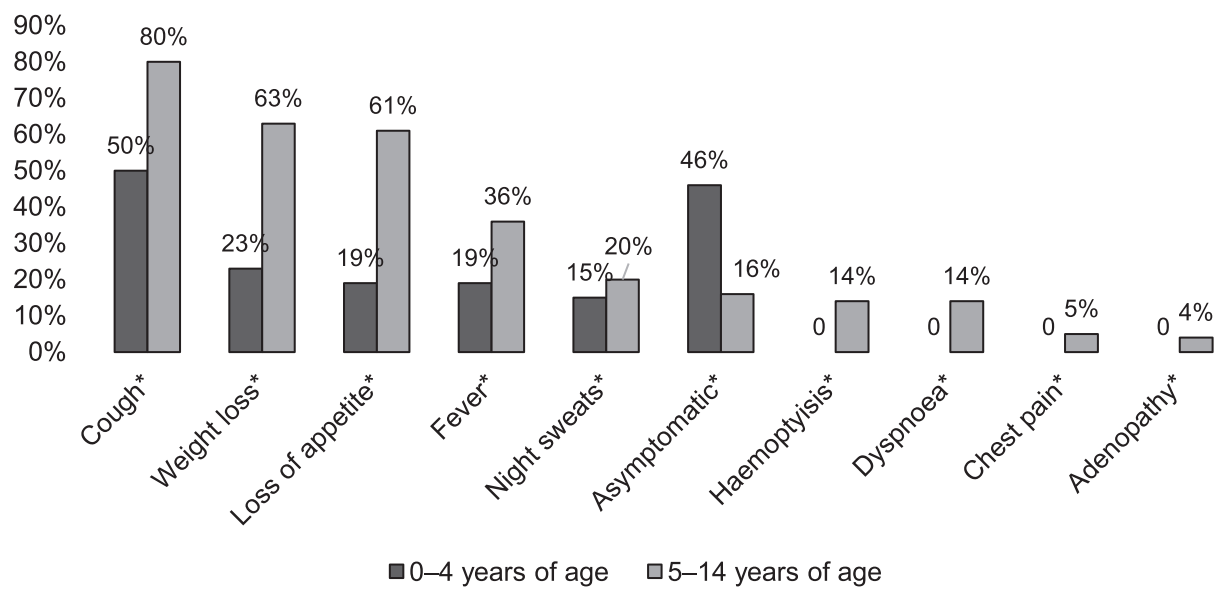

Figure 1 Clinical manifestations observed in patients at the time of TB diagnosis in children treated with second-line drugs in Lima Este, Peru, 2011-2015. * The difference between groups is statistically significant $(P<0.05)$. TB $=$ tuberculosis. 


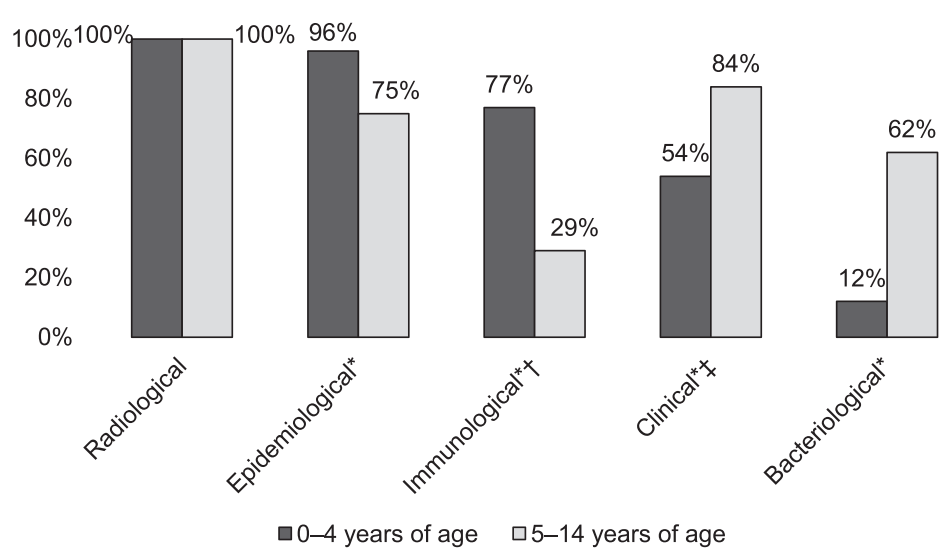

Figure 2 Criteria used for TB diagnosis in children treated with second-line drugs in Lima Este, Peru, 2011-2015. *The difference between the groups is statistically significant $(P<0.05)$. †Tuberculin skin test; ${ }^{\mp}$ TB-associated manifestations.

mandatory in Peru. The identification of two or more contacts with TB (index cases) in the family in a large proportion of children reveals a high risk of tuberculous infection among families in this area of Lima. Purified protein derivative (PPD) testing was used in only $50 \%$ of cases, as it is not generally available in Lima or worldwide; ${ }^{13}$ likewise, the absence of bacille Calmette-Guérin scarring in 32\% of cases calls for a review of strategies used for vaccination coverage at birth in Peru. The use and efficacy of nasogastric aspirate were limited, and sputum induction was not used. Both methods, if used adequately, have shown merit in childhood TB detection, and are compatible with molecular tests such as the Xpert ${ }^{\circledR}$ MTB/RIF test (Cepheid, Sunnyvale, CA, USA), which has been endorsed by the WHO for diagnostic use in childhood TB. ${ }^{14-16}$ Peru is one of the countries that benefit from subsidised Xpert equipment and cartridge prices; however, the real costs through the local distributor are still high, and there are many bureaucratic barriers to buying them with public funds. This is a task pending for the national authorities.

As expected, most children aged $<5$ years started empirical treatment for MDR-TB based on the diagnosis of their index case. In this age group, up to $46 \%$ of patients did not report any symptom, and given the similarities between TB symptoms and other common childhood diseases, such as asthma, bronchial obstruction syndrome and malnutrition, TB may have been overdiagnosed. Conversely, in the 5-14 years age group, clinical manifestations of the disease were present in $84 \%$ of cases. Radiology was a defining element in $100 \%$ of cases, and this finding confirms the importance of this test in paediatric populations; limitations stem from the need for a specialised radiologist or pulmonologist who can correctly read images (X-ray and computed tomography).

A high treatment success rate was seen in patients with confirmed MDR-TB or probable DR-TB using regimens based on Groups 1-4 of the WHO's 2011 update. ${ }^{9}$ In Chiang et al.'s study conducted in Peru, the treatment success rate was $77.2 \%$; however, children had a significantly higher risk of treatment failure or death if they had severe disease or were underweight. ${ }^{4}$ In our study, there were no severe cases, and children with some degree of malnutrition showed favourable evolution, as reported previously. ${ }^{10,11,17}$

Study limitations included the use of EMRs as the main source of information, which led to incomplete data reports using different formats, despite being part of the same health care network. Patients were

Table 3 TB treatment outcome in children aged $<15$ years treated with second-line drugs according to type of diagnosis

\begin{tabular}{|c|c|c|c|c|c|c|c|c|c|}
\hline & \multicolumn{2}{|c|}{ Probable DR-TB } & \multicolumn{2}{|c|}{ Confirmed MDR-TB } & \multirow{2}{*}{ 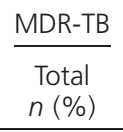 } & \multicolumn{2}{|c|}{ Isoniazid-resistant } & \multicolumn{2}{|c|}{ ADRs } \\
\hline & $\begin{array}{c}<5 \text { years } \\
n(\%)\end{array}$ & $\begin{array}{c}5-14 \text { years } \\
n(\%)\end{array}$ & $\begin{array}{c}<5 \text { years } \\
n(\%)\end{array}$ & $\begin{array}{c}5-14 \text { years } \\
n(\%)\end{array}$ & & $\begin{array}{c}<5 \text { years } \\
n(\%)\end{array}$ & $\begin{array}{c}5-14 \text { years } \\
n(\%)\end{array}$ & $\begin{array}{c}<5 \text { years } \\
n(\%)\end{array}$ & $\begin{array}{c}5-14 \text { years } \\
n(\%)\end{array}$ \\
\hline Cases, $n$ & 18 & 16 & 2 & 12 & 14 & 1 & 7 & 0 & 4 \\
\hline $\begin{array}{l}\text { Success } \\
\text { Cured } \\
\text { Completed treatment }\end{array}$ & $\begin{array}{l}16(89) \\
14(78) \\
2(11)\end{array}$ & $\begin{array}{l}14(88) \\
12(74) \\
2(13)\end{array}$ & $\begin{array}{l}2(100) \\
1(50) \\
1(50)\end{array}$ & $\begin{array}{c}10(83) \\
9(75) \\
1(8)\end{array}$ & $\begin{array}{l}12(86) \\
10(72) \\
2(14)\end{array}$ & $\begin{array}{c}1(100) \\
0 \\
1(100)\end{array}$ & $\begin{array}{l}6(86) \\
6(86) \\
0\end{array}$ & $\begin{array}{l}0 \\
0 \\
0\end{array}$ & $\begin{array}{l}4(100) \\
3(75) \\
1(25)\end{array}$ \\
\hline $\begin{array}{l}\text { Lost to follow-up } \\
\text { Failure } \\
\text { Death }\end{array}$ & $\begin{array}{c}2(11) \\
0 \\
0\end{array}$ & $\begin{array}{c}2(13) \\
0 \\
0\end{array}$ & $\begin{array}{l}0 \\
0 \\
0\end{array}$ & $\begin{array}{c}2(17) \\
0 \\
0\end{array}$ & $\begin{array}{c}2(14) \\
0 \\
0\end{array}$ & $\begin{array}{l}0 \\
0 \\
0\end{array}$ & $\begin{array}{c}1(14) \\
0 \\
0\end{array}$ & $\begin{array}{l}0 \\
0 \\
0\end{array}$ & $\begin{array}{l}0 \\
0 \\
0\end{array}$ \\
\hline
\end{tabular}

$\mathrm{TB}=$ tuberculosis; $\mathrm{DR}-\mathrm{TB}=$ drug-resistant $\mathrm{TB} ; \mathrm{MDR}-\mathrm{TB}=$ multidrug-resistant $\mathrm{TB} ; \mathrm{ADR}=$ adverse drug reactions. 

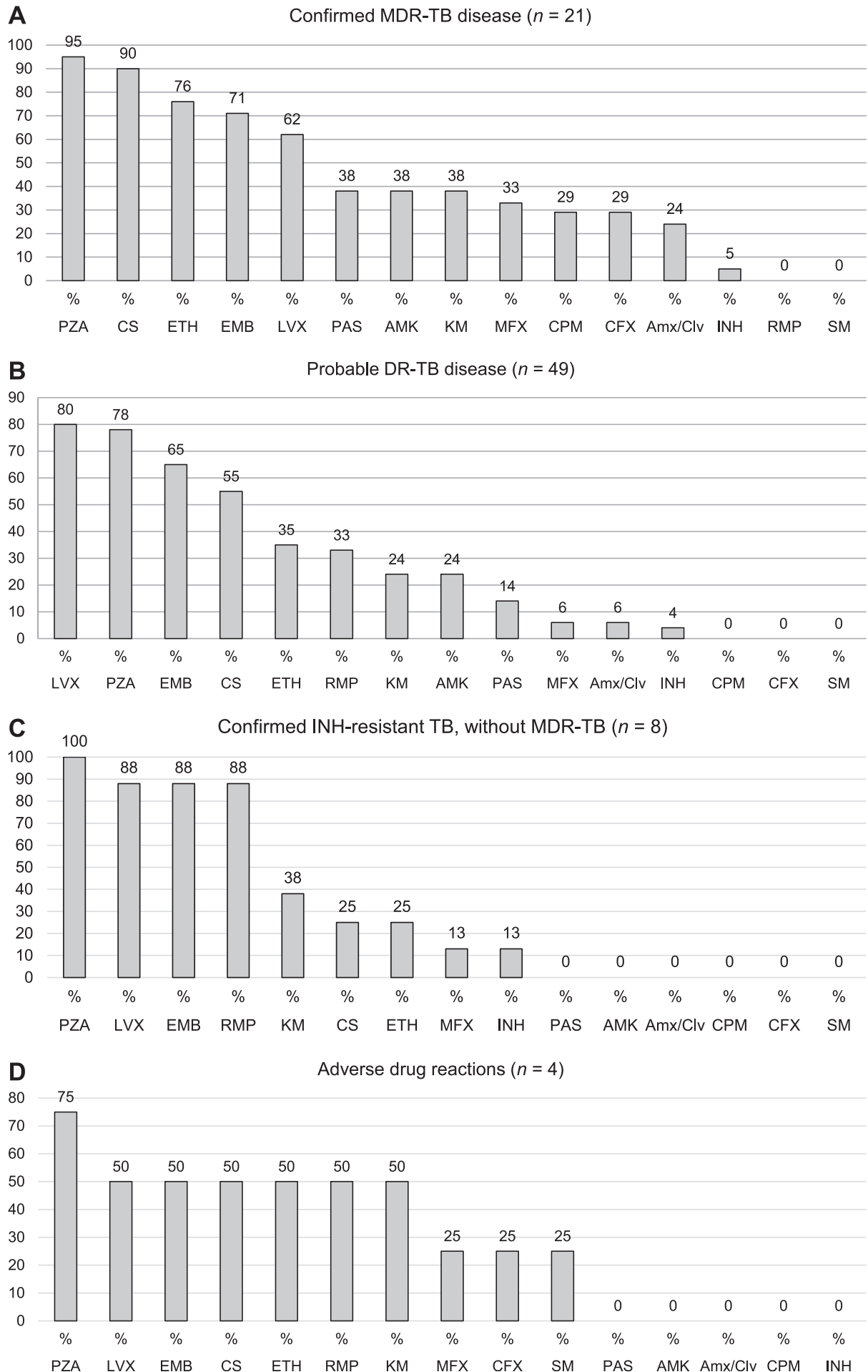

Figure 3 Drugs used to treat TB in children aged $<15$ years according to type of prescription. $\mathrm{MDR}-\mathrm{TB}=$ multidrug-resistant tuberculosis; $\mathrm{DR}-\mathrm{TB}=$ drug-resistant $\mathrm{TB} ; \mathrm{PZA}=$ pyrazinamide; $\mathrm{CS}=$ cycloserine; $\mathrm{ETH}=$ ethionamide; $\mathrm{EMB}=$ ethambutol; $\mathrm{LVX}=$ levofloxacin; $\mathrm{PAS}=$ para-aminosalicylic acid; $\mathrm{MFX}=$ moxifloxacin; CPM = capreomycin; CFX = ciprofloxacin; Amx/Clv = amoxicillin/ clavulanic acid; $\mathrm{RMP}=$ rifampicin; $\mathrm{KM}=$ kanamycin; $\mathrm{INH}=$ isoniazid; $\mathrm{SM}=$ streptomycin; $\mathrm{AMK}=$ amikacin.

excluded if EMRs could not be retrieved or information was too limited. We do not know if this exclusion created a bias, as we did not have access to information about these patients. Not being able to assess the frequency of ADRs was another limitation.
Despite the limitations faced by the facilities where the study was conducted, treatment success results were encouraging, and testified to the effort made by health care professionals to achieve treatment completion in each patient. 
In our opinion, the implications of this report for Peru's public health system (and possibly for a number industrialised countries as well) include the need to establish better sampling techniques, making gastric aspirates, sputum induction and other samples, such as faeces, more accessible. Molecular methods, such as Xpert for samples from children and liquid culture, should be introduced to reduce the use of empirical treatment. Treatment duration should be reduced using the new, shorter WHO regimen for MDR-TB recommended for children, and avoiding injectable drugs for MDR-TB cases with non-severe disease ${ }^{18}$ to reduce the $12 \%$ dropout rate reported in this study and the possibility of ADRs. Finally, new MDR-TB drugs such as delamanid, which has already been approved for use in paediatric populations, should be introduced promptly. ${ }^{19}$

\section{Acknowledgements}

This research was made possible with support from the United States Agency for International Development (USAID; Washington DC, USA) through the TREAT TB Cooperative Agreement (AIDGHN-A-00-08-00004). The contents are the responsibility of the authors and do not necessarily reflect the views of USAID or the United States Government. Additional support was provided through the Structured Operational Research and Training Initiative (SORT IT), a global partnership led by United Nations Childrens' Fund/United Nations Development Programme/World Bank/WHO Special Programme for Research and Training in Tropical Diseases (TDR) based at the World Health Organization. Conflicts of interest: none declared.

\section{References}

1 World Health Organization. Global tuberculosis report, 2017. WHO/HTM/TB/2017.23. Geneva, Switzerland: WHO, 2017.

2 Jenkins $\mathrm{H}$ E, Tolman A W, Yuen C M, et al. Incidence of multidrug-resistant tuberculosis disease in children: systematic review and global estimates. Lancet 2014; 383: 1572-1579.

3 Mandal N, Anand P K, Gautam S, et al. Diagnosis and treatment of paediatric tuberculosis: an insight review. Crit Rev Microbiol 2017; 43: 466-480.

4 Chiang S S, Starke J R, Miller A C, et al. Baseline predictors of treatment outcomes in children with multidrug-resistant tuberculosis: a retrospective cohort study. Clin Infect Dis 2016; 63: 1063-1071.

5 Ministerio de Salud, Dirección General de Epidemiología. Análisis de la situación epidemiológica de la tuberculosis en el Perú. Lima, Peru: MINSA, 2015. http://www.dge.gob.pe/portal/ docs/tools/tbc/asistbc.pdf. Accessed July 2018.
6 Alarcon V, Alarcon E, Figueroa C, et al. [Tuberculosis in Peru: epidemiological situation, progress and challenges for its control]. Rev Peru Med Exp Salud Publica 2017; 34: 299-310.

7 World Health Organization. Non commercial culture and drugsusceptibility testing methods for screening patients at risk for multidrug-resistant tuberculosis. Policy statement. WHO/ HTM/TB/2011.9. Geneva, Switzerland: WHO, 2011. http:// www.who.int/tb/publications/2011/mdr_tb_diagnostics_ 9789241501620/en/. Accessed July 2018.

8 World Health Organization. The use of molecular line-probe assays for the detection of resistance to isoniazid and rifampicin. WHO/HTM/TB/2016.12. Geneva, Switzerland: WHO, 2016. http://www.who.int/tb/publications/moleculartest-resistance/en/. Accessed July 2018.

9 World Health Organization. Guidelines for the programmatic management of drug-resistant tuberculosis. 2011 update. WHO/HTM/TB/2011.6. Geneva, Switzerland: WHO, 2011.

10 Ettehad D, Schaaf H S, Seddon J A, et al. Treatment outcomes for children with multidrug-resistant tuberculosis: a systematic review and meta-analysis. Lancet Infect Dis 2012; 12: 449-456.

11 Schaaf H S, Garcia-Prats A J, Hesseling A C, et al. Managing multidrug-resistant tuberculosis in children: review of recent developments. Curr Opin Infect Dis 2014; 27: 211-219.

12 Rigouts L. Clinical practice: diagnosis of childhood tuberculosis. Eur J Pediatr 2009; 168: 1285-1290.

13 Tebruegge M, Bogyi M, Soriano-Arandes A, et al. Shortage of purified protein derivative for tuberculosis testing. Lancet 2014; 384: 2026.

14 Bates M, O'Grady J, Maeurer M, et al. Assessment of the Xpert $\mathrm{MTB} / \mathrm{RIF}$ assay for diagnosis of tuberculosis with gastric lavage aspirates in children in sub-Saharan Africa: a prospective descriptive study. Lancet Infect Dis 2013; 13: 36-42.

15 Singh S, Singh A, Prajapati S, et al. Xpert MTB/RIF assay can be used on archived gastric aspirate and induced sputum samples for sensitive diagnosis of paediatric tuberculosis. BMC Microbiol 2015; 15: 191.

16 World Health Organization. Using the Xpert MTB/RIF assay to detect pulmonary and extrapulmonary tuberculosis and rifampicin resistance in adults and children. WHO/HTM/TB/ 2013.14. Geneva, Switzerland: WHO, 2013. http://www.who. int/tb/publications/xpert-mtb-rif-assay-diagnosis-meetingreport/en/. Accessed July 2018.

17 Galli L, Lancella L, Garazzino S, et al. Recommendations for treating children with drug-resistant tuberculosis. Pharmacol Res 2016; 105: 176-182.

18 World Health Organization. WHO treatment guidelines for drug-resistant tuberculosis. 2016 update. WHO/HTM/TB/ 2016.04. Geneva, Switzerland: WHO, 2016.

19 World Health Organization. The use of delamanid in the treatment of multidrug-resistant tuberculosis in children and adolescents: interim policy guidance WHO/HTM/TB/2016.14. Geneva, Switzerland: WHO, 2016. http://www.who.int/tb/ publications/Delamanid_interim_policy/en/. Accessed July 2018. 
O в Jе CтIF : Caractériser la tuberculose (TB) de l'enfant traitée par des médicaments de deuxième ligne (SLD) à Lima, Pérou.

SCHÉMA : Cas rapportés entre 2011 et 2015 dans six districts de Lima. Les résultats relatifs aux groupes d'âge $<5$ ans et entre 5 et 14 ans ont été comparés et les résultats du traitement ont été évalués.

RÉ SULTATS : Sur 96 cas rapportés, 82 ont été évalués. Parmi eux, 59\% ont été des garçons, d'âge médian 8 ans, et $32 \%$ étaient âgés de $<5$ ans. Un contact avec un cas de TB a été rapporté dans $82 \%$ des cas. Quatre-vingt-dix pour cent n'avaient jamais été traités, $\mathbf{9 8 \%}$ avaient une localisation pulmonaire et $50 \%$ ont eu un test cutané à la tuberculine (dérivé protéinique purifié), avec une réaction de $\geqslant 10 \mathrm{~mm}$ chez $88 \%$. Un frottis positif a été constaté chez $40 \%$ des enfants, tous dans le groupe d'âge 5 à 14 ans et $46 \%$ ont eu une culture positive. Seulement $26 \%$ ont eu une confirmation de TB multirésistante, dont $90 \%$ dans le groupe d'âge de 5 à 14 ans. Les SLD pour une TB confirmée ou probablement pharmacorésistante (DR) ont été administrés à tous les cas, avec une proportion élevée de succès (plus de $83 \%$ ), sans cas d'échec ni de décès et une proportion élevée de perdus de vue.

CONCLUSION : L'indication principale des SLD dans la TB de l'enfant a été le traitement empirique de la TB-DR due à un contact avec un ou plusieurs patients TB-DR identifiés. La confirmation bactériologique a été limitée, mais le taux de succès du traitement a été suffisant.
O BJETIVO: Caracterizar la tuberculosis (TB) en niños tratada con drogas de segunda línea (SLD) en Lima, Peru.

DISEÑO: Casos de TB en niños reportados entre 2011 y 2015 en seis distritos de Lima. Se compararon los resultados entre los menores de 5 años y de 5 a 14 años y se evaluó el resultado del tratamiento.

RESULTADOS: De los 96 casos reportados, se evaluaron a 82 . De ellos, el $59 \%$ fueron varones, la edad media fue de 8 años y el 32\% tenía menos de 5 años. El contacto con un caso índice de TB se notificó en el $82 \%$; $90 \%$ no tuvieron tratamiento previo, $98 \%$ tenía localización pulmonar y $50 \%$ se sometieron a prueba de tuberculina, con $\geqslant 10 \mathrm{~mm}$ en el $88 \%$. Se encontró un frotis positivo en el $40 \%$, todos en el grupo de 5 a 14 años, y el $46 \%$ tuvo un cultivo positivo. Solo el $26 \%$ tenía TB multirresistente confirmada, de los cuales el $90 \%$ tenían entre 5 y 14 años. En todos los casos se usaron SLD para tratar la TB confirmada o probablemente resistente a drogas (TB-DR), obteniendo una alta proporción de éxito (mayor al $83 \%$ ), sin casos de falla o muerte y una alta proporción de pérdidas durante el seguimiento.

CONCLUSIÓN: La principal indicación de SLD en la TB en niños fue el tratamiento empírico de la TB-DR debido al contacto con uno o más contactos con TB-DR. La confirmación bacteriológica fue limitada, pero el éxito del tratamiento fue adecuado. 